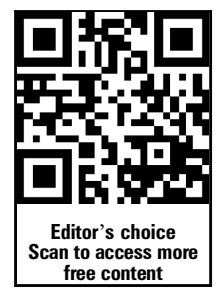

\title{
Anti-CarP antibodies in two large cohorts of patients with rheumatoid arthritis and their relationship to genetic risk factors, cigarette smoking and other autoantibodies
}

\author{
Xia Jiang, ${ }^{1}$ Leendert A Trouw, ${ }^{2}$ Tineke J van Wesemael, ${ }^{2}$ Jing Shi, ${ }^{2}$ \\ Camilla Bengtsson, ${ }^{1}$ Henrik Källberg, ${ }^{1}$ Vivi Malmström, ${ }^{3}$ Lena Israelsson, ${ }^{3}$ \\ Hulda Hreggvidsdottir, ${ }^{3}$ Willem Verduijn, ${ }^{4}$ Lars Klareskog, ${ }^{3}$ Lars Alfredsson, ${ }^{1,5}$ \\ Tom W J Huizinga, ${ }^{2}$ Rene E M Toes, ${ }^{2}$ Karin Lundberg, ${ }^{3}$ Diane van der Woude ${ }^{2}$
}

\begin{abstract}
Handling editor Tore K Kvien
- Additional material is published online only. To view please visit the journal online (http://dx.doi.org/10.1136/ annrheumdis-2013-205109)

For numbered affiliations see end of article.

Correspondence to Dr Diane van der Woude, Leiden University Medical Center, Department of Rheumatology, C1-40, PO Box 9600, 2300 RC Leiden, The Netherlands: dvanderwoude@lumc.n
\end{abstract}

$\mathrm{XJ}, \mathrm{LAT}, \mathrm{KL}$ and DvdW contributed equally.

Received 20 December 2013 Accepted 15 April 2014 Published Online First 8 May 2014

CrossMark

\section{SLinked}

- http://dx.doi.org/10.1136/ annrheumdis-2014-205307

To cite: Jiang $X$, Trouw LA, van Wesemael TJ, et al. Ann Rheum Dis 2014:73

1761-1768.

\section{ABSTRACT}

Introduction In rheumatoid arthritis (RA), several genetic risk factors and smoking are strongly associated with the presence of anticitrullinated protein antibodies (ACPA), while much less is known about risk factors for ACPA-negative RA. Antibodies against carbamylated proteins (anti-CarP) have been described in both ACPApositive and ACPA-negative RA patients. In this study, we have analysed the relationships among anti-CarP antibodies, ACPA, genetic risk factors (HLA-DRB1 alleles and PTPN22) and smoking in RA.

Methods Presence of antibodies to carbamylated fetal calf serum (CarP-FCS) and fibrinogen (CarP-Fib) was determined by inhouse ELISAs among RA cases in the Leiden Early Arthritis Clinic $(n=846)$ and in the Swedish Epidemiological Investigation of Rheumatoid Arthritis ( $n=1985)$ cohorts. ORs for associations with different HLA-DRB 1 alleles, PTPN22 genotypes and smoking were calculated separately for each cohort as well as in metaanalysis in RA subsets defined by the presence/absence of anti-CarP and anticyclic citrullinated peptide (anti-

CCP) antibodies.

Results In both cohorts, anti-CarP antibody positivity was mainly detected in the anti-CCP-positive population $(49 \%-73 \%)$, but also in the anti-CCP-negative population (8\%-14\%). No associations between antiCarP antibodies and HLA-DRB1 shared epitope alleles could be identified, while there were data to support an association between anti-CarP-FCS and HLA-DRB $1{ }^{*} 03$. Further analyses did not reveal any specific associations of anti-CarP antibodies with other HLA-DRB1 alleles, PTPN22 genotypes or smoking.

Conclusions Anti-CarP antibodies were present in both ACPA-positive and ACPA-negative RA. There were no significant associations among anti-CarP antibodies and HLA-DRB1 alleles, PTPN22 or smoking. These data suggest that different biological mechanisms may underlie anti-CarP versus anti-CCP antibody formation.

\section{INTRODUCTION}

The presence of autoantibodies is a distinctive feature of rheumatoid arthritis (RA). The two autoantibody systems, which are most commonly used as an aid for diagnosing/classifying RA, are rheumatoid factor (RF) and anticitrullinated protein antibodies (ACPA). ${ }^{1}$ These autoantibodies have good diagnostic properties and are associated with a more severe disease course. ${ }^{2}{ }^{3}$ Furthermore, they can predict future disease development and have been implicated in the pathogenesis of the disease. $^{4} 5$ The hypothesis that autoantibodies may be of pathophysiological importance has been fuelled by the discovery of strong associations among the most important genetic risk factors for RA (the HLA-DRB1 shared epitope (SE) alleles and PTPN22), the best characterised environmental risk factor smoking and the presence of autoantibodies, in particular ACPA. ${ }^{6}$ These epidemiological data form the basis of an aetiological hypothesis concerning the triggering of ACPA-positive RA, according to which smoking causes protein citrullination in the lungs, followed by presentation of citrullinated antigens by $H L A-D R B 1-S E$ molecules and, subsequently, in the context of a PTPN22 polymorphism, activation of auto-reactive $\mathrm{T}$ and $\mathrm{B}$ cells and ultimately the production of ACPA by B cells. ${ }^{8}$ In contrast, much less is known (and hypothesised) about the pathogenesis of ACPA-negative RA in terms of risk factors and biomarkers such as autoantibodies.

Recently, a new autoantibody system with antibodies directed against carbamylated proteins (anti-CarP antibodies) has been described in RA. These antibodies are present in both anticyclic citrullinated peptide (anti-CCP)-positive and -negative patients. ${ }^{9}$ Anti-CarP antibodies have been found to associate with joint destruction, measured as radiological progression, in anti-CCP-negative RA; $;^{9}$ and in an arthralgia cohort, anti-CarP antibodies were shown to predict the development of RA, independent of anti-CCP antibodies. ${ }^{10}$ These findings raised questions concerning the relationship among anti-CarP antibodies, anti-CCP antibodies and known genetic and environmental risk factors. If risk factors for the development of anti-CarP antibodies could be identified, this may also shed more light on the pathogenesis of ACPA-negative RA in general. Hence, in the present study, we have analysed the presence of anti-CarP antibodies in two large wellcharacterised early RA cohorts (one Swedish and one Dutch), and further investigated the association 
among anti-CarP status, anti-CCP status, HLA-DRB1 alleles, PTPN22 and smoking.

\section{METHODS}

\section{Study population}

This study is based on data from two European case-control cohorts, one Swedish and one Dutch. All participants provided written informed consent, and ethical permission was obtained from local ethical committees.

The Swedish Epidemiological Investigation of Rheumatoid Arthritis (EIRA), an ongoing population-based case-control study, comprises incident cases and controls aged 18-70 years, from a geographically defined area in the south/central part of Sweden. A case is defined as a person who was given a first time RA diagnosis, according to the 1987 American College of Rheumatology (ACR) criteria, ${ }^{11}$ by a rheumatologist. Controls were randomly selected from the national population register, matching cases on age, gender and residential area. Details of the study design have been reported elsewhere. ${ }^{12}$ Subjects completed a self-administrated questionnaire relating to life style and environmental exposures and donated blood at inclusion. The present study included 1985 RA cases and 2252 controls recruited between 1996 and 2006.

Data on Dutch RA cases were collected from the Leiden Early Arthritis Clinic (EAC) ${ }^{13}$ initiated in 1993, which includes patients with recent-onset arthritis (less than 2 years of symptoms) treated at the Leiden University Medical Center (LUMC). Further details have been described elsewhere. ${ }^{13}$ For the current analyses only baseline samples were used. Dutch controls for genetics were randomly selected from the collection of the section of Immunogenetics and Transplantation Immunology, at the Department of Immunohematology and Blood Transfusion, LUMC. The present study included 846 RA cases (diagnosed according to the 1987 ACR criteria ${ }^{11}$ ) and 1211 controls.

\section{Detection of anti-CarP antibodies and anti-CCP2 antibodies}

Antibodies directed against CarP were detected using two carbamylated antigens, either carbamylated fetal calf serum (FCS) or carbamylated fibrinogen (Fib) using inhouse ELISAs as described before (EAC) ${ }^{9}$ or with some modifications (EIRA); Nunc highbinding plates (Thermo Scientific) were coated with $10 \mu \mathrm{g} / \mathrm{mL}$ of CarP-Fib, CarP-FCS, or the non-carbamylated versions, Fib and FCS, diluted in phosphate buffered saline (PBS) (pH 9), at $4^{\circ} \mathrm{C}$ overnight. Plates were blocked with $2 \%$ bovine serum albumin (BSA) (Sigma) in PBS $\left(\mathrm{pH}\right.$ 9) for $1 \mathrm{~h}$ at $4^{\circ} \mathrm{C}$, and further incubated for $4 \mathrm{~h}$ at $4^{\circ} \mathrm{C}$ with serum diluted 1:50 in radioimmunoprecipitation assay (RIA) buffer $(10 \mathrm{mM}$ Tris, $1 \%$ BSA, $350 \mathrm{mM} \mathrm{NaCl}, 1 \%$ Triton-X, $0.5 \%$ sodium deoxycholate, $0.1 \%$ SDS). Bound antibodies were detected after incubation for $2 \mathrm{~h}$ at $4{ }^{\circ} \mathrm{C}$ with horseradish peroxidase-conjugated goat antihuman IgG (Jacksson), diluted 1:10 000 in RIA buffer, followed by the addition of tetramethylbenzidine (TMB) substrate (Sigma). The colour reaction was stopped by the addition of $0.5 \mathrm{M} \mathrm{H}_{2} \mathrm{SO}_{4}$, and absorbance was measured at $450 \mathrm{~nm}$. Optical density was transformed into arbitrary units $(\mathrm{AU} / \mathrm{mL})$ using the titration curve of a serum pool from three anti-CarP antibody-positive serum samples. Background signals of Fib and FCS were subtracted from the CarP-Fib and CarP-FCS signals, respectively. Cut-off for positivity was equivalent to 2 SDs above the mean of 316 EIRA controls.

Anti-CCP IgG was measured using the second-generation ELISA (anti-CCP2) (Immunoscan CCPlus, Euro-Diagnostica) according to the manufacturer's instructions, with a cut-off for positivity set to $25 \mathrm{AU} / \mathrm{mL}$.

\section{Genotyping}

The genotyping procedures for HLA-DRB1 alleles have been described previously. ${ }^{14}{ }^{15}$ In short, genotyping of DNA samples from both EIRA (1348 cases/976 controls) and EAC (846 cases/ 1211 controls) subjects was performed by sequence-specific primer PCR. An interpretation table for the HLA-DRB1 lowresolution kit was used to determine the specific genotype according to manufacturer's recommendations. The HLA-DRB1 allelic subgroups analysed in the present study were: DRB1*01, "03, "04, "07, "08, "09, "10, "11, "12, "13, "14, "15 and "16. In EIRA, HLA-DRB1*01 (except DRB1"0103), "04 and"10 were classified as SE alleles. In EAC, a specific probe was used to detect the presence of the SE sequence, thereby classifying DRB1"01:01,"01:02, "04:01, "04:04, "04:05, "04:08 and *10:01 as SE alleles.

The protein tyrosine phosphatase gene (PTPN22 rs2476601) was genotyped on 3227 EIRA subjects (1943 cases/1284 controls) and 1062 EAC subjects (651 cases/411 controls). Detailed information regarding the typing procedure is described elsewhere. ${ }^{16}{ }^{17}$ Within both datasets, the information on genotyping (HLA, PTPN22) was not available for the exact same number of individuals as indicated above, without any evidence for a systematic bias.

\section{Cigarette smoking}

Information regarding smoking in the EIRA study was collected via questionnaires at inclusion. ${ }^{18}$ Subjects were categorised as 'ever smokers' or 'never smokers', where 'ever smokers' comprise former and current cigarette smokers. In total, concomitant genetic and smoking data from 1727 EIRA cases and 1913 EIRA controls were available for analyses.

Information on cigarette smoking habits was collected at inclusion in the EAC study through interviews conducted by trained research nurses. ${ }^{19}$ Patients were asked whether they had ever smoked or not. Data were available on 852 RA cases.

\section{Statistical analysis}

First, EIRA and EAC data were analysed separately, using unconditional logistic regression models, to calculate ORs with $95 \%$ CIs, for the development of RA in association with different HLA-DRB1 alleles, SE alleles, PTPN22 and smoking. We categorised RA cases into four subsets based on the presence/ absence of anti-CCP IgG and anti-CarP (CarP-Fib or CarP-FCS) IgG. All analyses in EIRA were performed with adjustment for the matching variables (age, gender and residential area). A dominant genetic model that estimates the effect of the presence of a certain allele (irrespective of one or two copies) was used for all analyses, with subjects who were non-carriers as reference category. Since smoking data were not available in EAC controls, double-negative RA cases (CCP-/CarP-) were used as the reference category, and then compared with the other RA subgroups (ie, $\mathrm{CCP}-/ \mathrm{CarP}+, \mathrm{CCP}+/ \mathrm{CarP}-$ and $\mathrm{CCP}+/ \mathrm{CarP}+$ ) when analysing the association with smoking. In addition, in EIRA, we also performed the association analysis of smoking using EIRA controls as a referent.

Due to the strong effect of SE alleles among anti-CCP-positive RA cases, we also analysed the association with non-SE HLA-DRB1 alleles after stratification for the presence of SE alleles. For each non-SE allele (eg, $D R B 1 * 03$ ), all six possible genotypes were taken into account: group A, DRB1*03/DRB1*03; group $\mathrm{B}, D R B 1^{*} 03 / \mathrm{x}$; group $\mathrm{C}, \mathrm{x} / \mathrm{x}$; group $\mathrm{D}, \mathrm{SE} / \mathrm{SE}$; group $\mathrm{E}$, $\mathrm{SE} / \mathrm{x}$; and group $\mathrm{F}, \mathrm{SE} / \mathrm{DRB1} 1^{*} 03$ (with $\mathrm{x}$ denoting alleles that were neither SE nor $D R B 1^{*} 03$ ). For the SE-negative stratum, the 
effect in groups $\mathrm{A}$ and $\mathrm{B}$ was investigated by using group $\mathrm{C}$ as reference category. For the SE-positive stratum, the effect of group $\mathrm{F}$ was analysed by using group $\mathrm{E}$ as the reference category.

Subsequently, we performed a meta-analysis by using the effect size ( $\beta$ ) and SEs from the two separate analyses (EIRA and EAC). Here, we applied a random-effect approach for all the comparisons to allow for inbetween-study heterogeneity to be incorporated into the calculations.

All analyses were performed using software SAS (V.9.3; Cary, North Carolina, USA) and Stata (V.11.0; STATA Corp, College Station, Texas, USA). All p values were two-sided.

\section{RESULTS}

\section{Frequency of anti-CarP antibodies, in relation to anti-CCP} $\lg \mathrm{G}$, in RA

Anti-CarP-FCS antibodies could be detected in $35.6 \%$ of EIRA patients and $44.9 \%$ of EAC patients; while anti-CarP-Fib antibodies were detected in $42.6 \%$ and $38.0 \%$, respectively, in EIRA and EAC (figure 1A and B). Most anti-CarP antibody-positive RA patients were found in the anti-CCP antibody-positive population (49\%-73\%), while a smaller subset was found in the anti-CCP antibody-negative populations (8\%-14\%) of both cohorts. The differences were statistically significant $(p<0.0001$ for both EAC and EIRA). Hence, double-positive and double-negative as well as anti-CarP antibody single positive and anti-CCP antibody single positive subsets of RA could be identified in both cohorts (figure 1A and B).

\section{Impact of HLA-DRB1-SE alleles on disease risk in different RA subsets}

We then proceeded to investigate associations of genetic and environmental risk factors with the presence of anti-CarP antibodies, in relation to anti-CCP IgG status. We first analysed associations of different RA subsets with HLA-DRB1-SE alleles, and found a significant strong risk effect in anti-CCP-positive RA, regardless of anti-CarP antibody status, in both EIRA and EAC, as well as in the meta-analysis. When analysing the difference between $\mathrm{CCP}+/ \mathrm{CarP}-$ and $\mathrm{CCP}+/ \mathrm{CarP}+$ patients, the strongest association was found in double-positive $(\mathrm{CCP}+/ \mathrm{CarP}+) \mathrm{RA}$ in both cohorts, with the exception of anti-CarP-FCS in EAC (data not shown). In contrast, we could not find statistically significant associations of SE specifically with anti-CarP antibodies (ie, with $\mathrm{CCP}-/ \mathrm{CarP}+\mathrm{RA}$ subset) (table 1). Consistent with previous reports, all three SE alleles (HLA-DRB1*01,*04 and *10) contributed to an increased risk specifically for anti-CCP antibodypositive RA (rather than anti-CarP antibody-positive RA), with HLA-DRB1*04 displaying the strongest association (see online supplementary tables S1A,B and S2A,B).

\section{Association of different $H L A-D R B 1$ alleles and disease risk in different RA subsets}

Since we could not identify any specific associations of SE alleles with anti-CarP antibodies, we next explored the relationship between other HLA-DRB1 alleles and anti-CarP antibody-positive RA. In unstratified analyses, where presence/absence of SE was not taken into account, HLA-DRB1*03, *07, *08, *13, *14 and *15 were all associated with protection against anti-CCP-positive RA, with a more pronounced effect seen in the double-positive (CCP $+/ \mathrm{CarP}+$ ) subgroups. However, after stratification for SE, only HLA-DRB1*13 alleles continued to be associated with protection against anti-CCP-positive RA, while the protective effects of all other alleles were lost (see online supplementary tables S1A,B and S2A,B).

For $H L A-D R B 1 * 03$, we observed a consistent risk association with the CCP-/CarP-FCS + subgroup in both cohorts, with a meta-analysis OR of approximately 2.5 in both SE-positive and
A

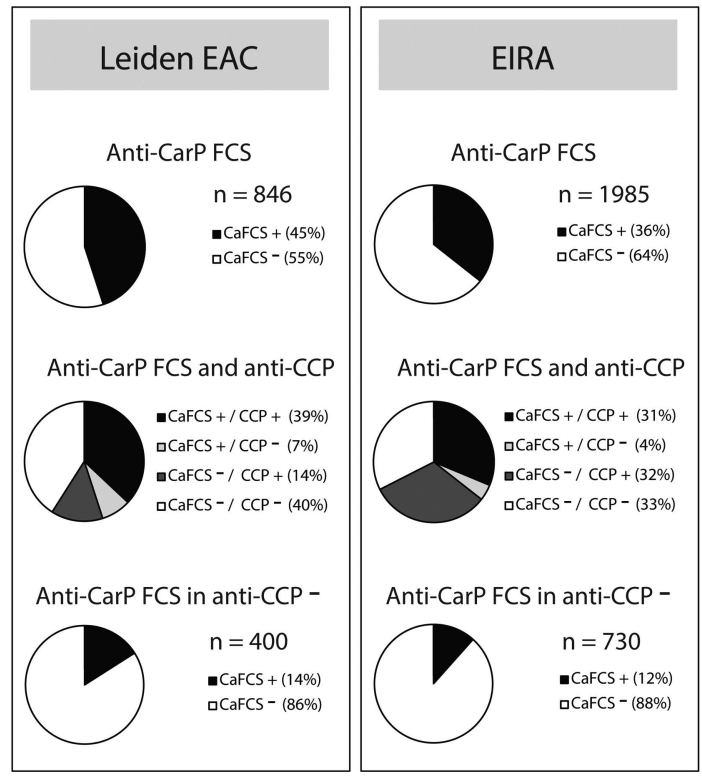

B

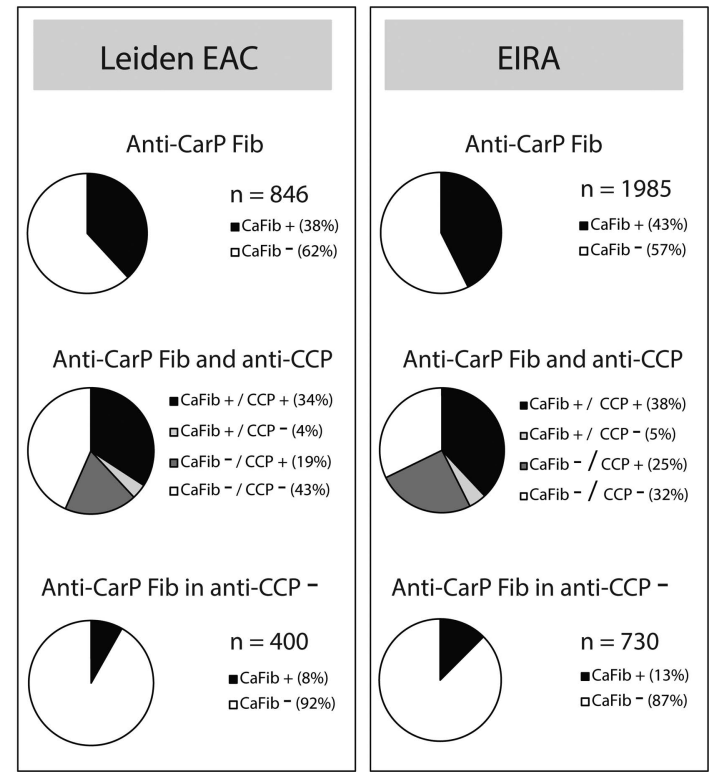

Figure 1 Disease subsets based on presence (+)/absence (-) of anti-CarP and anticyclic citrullinated peptide (anti-CCP) antibodies, as measured by ELISA, in two early rheumatoid arthritis (RA) cohorts, the Leiden Early Arthritis Clinic (EAC) $(n=846)$ and the Swedish Epidemiological Investigation of Rheumatoid Arthritis (EIRA) ( $n=1985)$. (A) anti-CarP-FCS data in Leiden EAC (left panel) and Swedish EIRA (right panel); (B) anti-CarP-Fib data in Leiden EAC (left panel) and Swedish EIRA (right panel). (Top panel) Only anti-CarP IgG data; (middle panel) anti-CarP IgG and anti-CCP IgG data; (bottom panel) anti-CarP IgG data in the anti-CCP-negative subsets. Percentages (\%) of patients in each subset are shown in brackets. In the panels, anti-CarP-FCS antibodies are abbreviated as CaFCS, anti-CarP-Fib antibodies as CaFib and anti-CCP antibodies as CCP. FCS, fetal calf serum. 
Table 1 Meta-analysis for disease risk in different rheumatoid arthritis (RA) subgroups divided by the presence/absence of anti-CarP and anticyclic citrullinated peptide (anti-CCP) antibodies in subjects exposed to any HLA-DRB1 SE alleles compared with non-exposed subjects

\begin{tabular}{|c|c|c|c|c|c|c|}
\hline \multirow[b]{2}{*}{ Group } & \multirow[b]{2}{*}{ Cohort } & \multicolumn{2}{|l|}{ SE } & \multirow[b]{2}{*}{$\mathrm{OR}^{*}$} & \multirow[b]{2}{*}{$95 \% \mathrm{Cl}$} & \multirow[b]{2}{*}{$p$ Value } \\
\hline & & None N (\%) & Any N (\%) & & & \\
\hline \multicolumn{7}{|l|}{ CarP-FCS } \\
\hline Controls & $\begin{array}{l}\text { Leiden EAC } \\
\text { Swedish EIRA } \\
\text { Meta-analysis }\end{array}$ & $\begin{array}{l}674(55.7) \\
635(49.7)\end{array}$ & $\begin{array}{l}537(44.3) \\
643(50.3)\end{array}$ & $\begin{array}{l}1.0 \\
1.0 \\
1.0\end{array}$ & $\begin{array}{l}\text { Ref. } \\
\text { Ref. } \\
\text { Ref. }\end{array}$ & $\begin{array}{l}- \\
- \\
-\end{array}$ \\
\hline CCP-/CarP-FCS- & $\begin{array}{l}\text { Leiden EAC } \\
\text { Swedish EIRA } \\
\text { Meta-analysis }\end{array}$ & $\begin{array}{l}147(52.5) \\
286(45.0)\end{array}$ & $\begin{array}{l}133(47.5) \\
350(55.0)\end{array}$ & $\begin{array}{l}1.14 \\
1.22 \\
1.19\end{array}$ & $\begin{array}{l}0.88 \text { to } 1.47 \\
1.01 \text { to } 1.49 \\
1.02 \text { to } 1.39\end{array}$ & $\begin{array}{l}0.34 \\
0.043 \\
0.028\end{array}$ \\
\hline CCP-/CarP-FCS+ & $\begin{array}{l}\text { Leiden EAC } \\
\text { Swedish EIRA } \\
\text { Meta-analysis }\end{array}$ & $\begin{array}{l}29(56.9) \\
43(50.6)\end{array}$ & $\begin{array}{l}22(43.1) \\
42(49.4)\end{array}$ & $\begin{array}{l}0.95 \\
0.92 \\
0.93\end{array}$ & $\begin{array}{l}0.54 \text { to } 1.68 \\
0.59 \text { to } 1.44 \\
0.66 \text { to } 1.32\end{array}$ & $\begin{array}{l}0.87 \\
0.73 \\
0.69\end{array}$ \\
\hline $\mathrm{CCP}+/ \mathrm{CarP}-\mathrm{FCS}-$ & $\begin{array}{l}\text { Leiden EAC } \\
\text { Swedish EIRA } \\
\text { Meta-analysis }\end{array}$ & $\begin{array}{r}20(20.4) \\
111(17.7)\end{array}$ & $\begin{array}{r}78(79.6) \\
515(82.3)\end{array}$ & $\begin{array}{l}4.90 \\
4.63 \\
4.68\end{array}$ & $\begin{array}{l}2.96 \text { to } 8.10 \\
3.65 \text { to } 5.86 \\
3.78 \text { to } 5.80\end{array}$ & $\begin{array}{l}<0.001 \\
<0.001 \\
<0.001\end{array}$ \\
\hline $\mathrm{CCP}+/ \mathrm{CarP}-\mathrm{FCS}+$ & $\begin{array}{l}\text { Leiden EAC } \\
\text { Swedish EIRA } \\
\text { Meta-analysis }\end{array}$ & $\begin{array}{l}57(20.4) \\
78(12.7)\end{array}$ & $\begin{array}{l}222(79.6) \\
536(87.3)\end{array}$ & $\begin{array}{l}4.89 \\
6.99 \\
5.91\end{array}$ & $\begin{array}{l}3.58 \text { to } 6.68 \\
5.37 \text { to } 9.10 \\
4.16 \text { to } 8.38\end{array}$ & $\begin{array}{l}<0.001 \\
<0.001 \\
<0.001\end{array}$ \\
\hline \multicolumn{7}{|l|}{ CarP-Fib } \\
\hline Controls & $\begin{array}{l}\text { Leiden EAC } \\
\text { Swedish EIRA } \\
\text { Meta-analysis }\end{array}$ & $\begin{array}{l}674(55.7) \\
635(49.7)\end{array}$ & $\begin{array}{l}537(44.3) \\
643(50.3)\end{array}$ & $\begin{array}{l}1.0 \\
1.0 \\
1.0\end{array}$ & $\begin{array}{l}\text { Ref. } \\
\text { Ref. } \\
\text { Ref. }\end{array}$ & $\begin{array}{l}- \\
- \\
-\end{array}$ \\
\hline CCP-/CarP-Fib- & $\begin{array}{l}\text { Leiden EAC } \\
\text { Swedish EIRA } \\
\text { Meta-analysis }\end{array}$ & $\begin{array}{l}168(53.5) \\
290(46.0)\end{array}$ & $\begin{array}{l}146(46.5) \\
340(54.0)\end{array}$ & $\begin{array}{l}1.09 \\
1.16 \\
1.13\end{array}$ & $\begin{array}{l}0.85 \text { to } 1.40 \\
0.96 \text { to } 1.41 \\
0.97 \text { to } 1.32\end{array}$ & $\begin{array}{l}0.49 \\
0.14 \\
0.11\end{array}$ \\
\hline CCP-/CarP-Fib+ & $\begin{array}{l}\text { Leiden EAC } \\
\text { Swedish EIRA } \\
\text { Meta-analysis }\end{array}$ & $\begin{array}{l}12(41.4) \\
39(42.9)\end{array}$ & $\begin{array}{l}17(58.6) \\
52(57.1)\end{array}$ & $\begin{array}{l}1.78 \\
1.35 \\
1.45\end{array}$ & $\begin{array}{l}0.84 \text { to } 3.76 \\
0.87 \text { to } 2.08 \\
0.99 \text { to } 2.11\end{array}$ & $\begin{array}{l}0.13 \\
0.18 \\
0.05\end{array}$ \\
\hline $\mathrm{CCP}+/$ CarP-Fib- & $\begin{array}{l}\text { Leiden EAC } \\
\text { Swedish EIRA } \\
\text { Meta-analysis }\end{array}$ & $\begin{array}{l}35(26.7) \\
90(18.3)\end{array}$ & $\begin{array}{r}96(73.3) \\
403(81.7)\end{array}$ & $\begin{array}{l}3.44 \\
4.50 \\
4.12\end{array}$ & $\begin{array}{l}2.30 \text { to } 5.15 \\
3.48 \text { to } 5.82 \\
3.22 \text { to } 5.28\end{array}$ & $\begin{array}{l}<0.001 \\
<0.001 \\
<0.001\end{array}$ \\
\hline $\mathrm{CCP}+/$ CarP-Fib+ & $\begin{array}{l}\text { Leiden EAC } \\
\text { Swedish EIRA } \\
\text { Meta-analysis }\end{array}$ & $\begin{array}{l}44(17.3) \\
99(13.3)\end{array}$ & $\begin{array}{l}210(82.7) \\
648(86.7)\end{array}$ & $\begin{array}{l}5.99 \\
6.58 \\
6.38\end{array}$ & $\begin{array}{l}4.25 \text { to } 8.45 \\
5.17 \text { to } 8.37 \\
5.24 \text { to } 7.77\end{array}$ & $\begin{array}{l}<0.001 \\
<0.001 \\
<0.001\end{array}$ \\
\hline
\end{tabular}

SE-negative strata (table 2). We observed a minor association of HLA-DRB1*03 with anti-CCP/anti-CarP-FCS double-negative subset, albeit with lower ORs (approximately 1.5 in the meta-analysis, for both strata). When the analysis was performed using $\mathrm{CCP}-/ \mathrm{CarP}-$ patients as reference category, the differences between the two ORs were not statistically significant (see online supplementary table S3). Thus, although the effect observed in the CCP-/CarP-FCS+ group was considerably more pronounced, it was not statistically significantly higher than the effect observed in double-negative group.

No consistent associations between other HLA-DRB1 alleles and the CCP-/CarP+ subgroup were found across cohorts or across anti-CarP antibody specificities.

\section{Association between PTPN22 gene and different RA subsets}

We then performed similar association analyses for PTPN22, the second most important genetic risk factor identified for RA. The PTPN22 polymorphism was not associated with anti-CarP-positive disease, although at first glance there might appear to be an association with CCP-/CarP-FCS + RA in EIRA (table 3). However, the estimate was neither replicated in the EAC cohort nor in the meta-analysis. In the meta-analysis, there was a consistent association between PTPN22 and the presence of anti-CCP, but not anti-CarP antibodies. In EIRA we could also observe a positive association of PTPN22 with the double-negative subset (in line with previously published data on the marginally significant risk effect of PTPN22 in anti-CCP-negative $\mathrm{RA}^{20}$ ), which could not be seen in EAC.

\section{Association between smoking and different RA subsets}

Finally, we explored the association between RA subgroups and cigarette smoking, the best known environmental risk factor for (ACPA-positive) RA. In accordance with previously published data, smoking associated with anti-CCP antibody-positive RA. There was no specific association with anti-CarP antibodypositive RA (table 4). In addition to the analyses presented in table 4, we performed a separate analysis, using only EIRA data, where we have detailed information on smoking habits also for controls (in addition to RA cases). Comparing different RA case subsets with the control group generated similar results on the association with smoking (data not shown), as did the first analysis, where we used the antibody-negative RA subset as referent.

\section{DISCUSSION}

The detection of autoantibodies in sera of RA patients has opened up possibilities of subgrouping the RA population to allow more precise prognosis and possibly therapeutic management. Next to the well-known IgM RF and ACPA, a number of new autoantibodies have been reported to be useful in this 
Table 2 Meta-analysis for disease risk in different rheumatoid arthritis (RA) subgroups divided by the presence/absence of anti-CarP and anticyclic citrullinated peptide (anti-CCP) antibodies in subjects exposed to any HLA-DRB1-03 alleles compared with non-exposed subjects, stratified by shared epitope status

\begin{tabular}{|c|c|c|c|c|c|c|c|c|c|c|c|}
\hline \multirow[b]{3}{*}{ Group } & \multirow[b]{3}{*}{ Cohort } & \multicolumn{5}{|c|}{ Shared epitope-positive stratum } & \multicolumn{5}{|c|}{ Shared epitope-negative stratum } \\
\hline & & \multicolumn{2}{|l|}{ Any $\mathrm{DRB} 1 * 03$} & \multirow[b]{2}{*}{$O R^{*}$} & \multirow[b]{2}{*}{$95 \% \mathrm{Cl}$} & \multirow[b]{2}{*}{ p Value } & \multicolumn{2}{|l|}{ Any $\mathrm{DRB} 1 * 03$} & \multirow[b]{2}{*}{$O R^{*}$} & \multirow[b]{2}{*}{$95 \% \mathrm{Cl}$} & \multirow[b]{2}{*}{$p$ Value } \\
\hline & & None N (\%) & Any N (\%) & & & & None N (\%) & Any N (\%) & & & \\
\hline \multicolumn{12}{|l|}{ CarP-FCS } \\
\hline Controls & $\begin{array}{l}\text { Leiden EAC } \\
\text { Swedish EIRA } \\
\text { Meta-analysis }\end{array}$ & $\begin{array}{l}385(83.7) \\
318(83.0)\end{array}$ & $\begin{array}{l}75(16.3) \\
65(17.0)\end{array}$ & $\begin{array}{l}1.0 \\
1.0 \\
1.0\end{array}$ & $\begin{array}{l}\text { Ref. } \\
\text { Ref. } \\
\text { Ref. }\end{array}$ & $\begin{array}{l}- \\
- \\
-\end{array}$ & $\begin{array}{l}480(71.2) \\
338(67.2)\end{array}$ & $\begin{array}{l}194(28.8) \\
165(32.8)\end{array}$ & $\begin{array}{l}1.0 \\
1.0 \\
1.0\end{array}$ & $\begin{array}{l}\text { Ref. } \\
\text { Ref. } \\
\text { Ref. }\end{array}$ & $\begin{array}{l}- \\
- \\
-\end{array}$ \\
\hline CCP-/CarP-FCS- & $\begin{array}{l}\text { Leiden EAC } \\
\text { Swedish EIRA } \\
\text { Meta-analysis }\end{array}$ & $\begin{array}{l}84(75.0) \\
166(78.3)\end{array}$ & $\begin{array}{l}28(25.0) \\
46(21.7)\end{array}$ & $\begin{array}{l}1.71 \\
1.32 \\
1.48\end{array}$ & $\begin{array}{l}1.04 \text { to } 2.81 \\
0.85 \text { to } 2.04 \\
1.06 \text { to } 2.05\end{array}$ & $\begin{array}{l}0.030 \\
0.22 \\
0.020\end{array}$ & $\begin{array}{r}87(59.2) \\
128(60.4)\end{array}$ & $\begin{array}{l}60(40.8) \\
84(39.6)\end{array}$ & $\begin{array}{l}1.71 \\
1.28 \\
1.47\end{array}$ & $\begin{array}{l}1.18 \text { to } 2.47 \\
0.91 \text { to } 1.81 \\
1.11 \text { to } 1.95\end{array}$ & $\begin{array}{l}0.005 \\
0.16 \\
0.008\end{array}$ \\
\hline CCP-/CarP-FCS+ & $\begin{array}{l}\text { Leiden EAC } \\
\text { Swedish EIRA } \\
\text { Meta-analysis }\end{array}$ & $\begin{array}{l}14(66.7) \\
18(66.7)\end{array}$ & $\begin{array}{l}7(33.3) \\
9(33.3)\end{array}$ & $\begin{array}{l}2.57 \\
2.69 \\
2.63\end{array}$ & $\begin{array}{l}1.00 \text { to } 6.57 \\
1.07 \text { to } 6.72 \\
1.36 \text { to } 5.08\end{array}$ & $\begin{array}{l}0.050 \\
0.035 \\
0.004\end{array}$ & $\begin{array}{l}13(44.8) \\
15(53.6)\end{array}$ & $\begin{array}{l}16(55.2) \\
13(46.4)\end{array}$ & $\begin{array}{l}3.04 \\
1.95 \\
2.47\end{array}$ & $\begin{array}{l}1.44 \text { to } 6.45 \\
0.88 \text { to } 4.35 \\
1.43 \text { to } 4.27\end{array}$ & $\begin{array}{l}0.004 \\
0.10 \\
0.001\end{array}$ \\
\hline $\mathrm{CCP}+/ \mathrm{CarP}-\mathrm{FCS}-$ & $\begin{array}{l}\text { Leiden EAC } \\
\text { Swedish EIRA } \\
\text { Meta-analysis }\end{array}$ & $\begin{array}{l}42(77.8) \\
195(81.3)\end{array}$ & $\begin{array}{l}12(22.2) \\
45(18.7)\end{array}$ & $\begin{array}{l}1.47 \\
1.17 \\
1.25\end{array}$ & $\begin{array}{l}0.74 \text { to } 2.92 \\
0.75 \text { to } 1.81 \\
0.86 \text { to } 1.81\end{array}$ & $\begin{array}{l}0.28 \\
0.50 \\
0.24\end{array}$ & $\begin{array}{l}15(75.0) \\
48(61.5)\end{array}$ & $\begin{array}{r}5(25.0) \\
30(38.5)\end{array}$ & $\begin{array}{l}0.83 \\
1.33 \\
1.21\end{array}$ & $\begin{array}{l}0.30 \text { to } 2.30 \\
0.80 \text { to } 2.22 \\
0.77 \text { to } 1.90\end{array}$ & $\begin{array}{l}0.83 \\
0.28 \\
0.41\end{array}$ \\
\hline $\mathrm{CCP}+/ \mathrm{CarP}-\mathrm{FCS}+$ & $\begin{array}{l}\text { Leiden EAC } \\
\text { Swedish EIRA } \\
\text { Meta-analysis }\end{array}$ & $\begin{array}{l}126(80.3) \\
158(81.0)\end{array}$ & $\begin{array}{l}31(19.7) \\
37(19.0)\end{array}$ & $\begin{array}{l}1.26 \\
1.31 \\
1.29\end{array}$ & $\begin{array}{l}0.79 \text { to } 2.01 \\
0.82 \text { to } 2.09 \\
0.92 \text { to } 1.79\end{array}$ & $\begin{array}{l}0.32 \\
0.26 \\
0.14\end{array}$ & $\begin{array}{l}38(66.7) \\
35(70.0)\end{array}$ & $\begin{array}{l}19(33.3) \\
15(30.0)\end{array}$ & $\begin{array}{l}1.24 \\
0.84 \\
1.05\end{array}$ & $\begin{array}{l}0.70 \text { to } 2.20 \\
0.43 \text { to } 1.63 \\
0.68 \text { to } 1.62\end{array}$ & $\begin{array}{l}0.47 \\
0.60 \\
0.82\end{array}$ \\
\hline \multicolumn{12}{|l|}{ CarP-Fib } \\
\hline Controls & $\begin{array}{l}\text { Leiden EAC } \\
\text { Swedish EIRA } \\
\text { Meta-analysis }\end{array}$ & $\begin{array}{l}385(83.7) \\
318(83.0)\end{array}$ & $\begin{array}{l}75(16.3) \\
65(17.0)\end{array}$ & $\begin{array}{l}1.0 \\
1.0 \\
1.0\end{array}$ & $\begin{array}{l}\text { Ref. } \\
\text { Ref. } \\
\text { Ref. }\end{array}$ & $\begin{array}{l}- \\
- \\
-\end{array}$ & $\begin{array}{l}480(71.2) \\
338(67.2)\end{array}$ & $\begin{array}{l}194(28.8) \\
165(32.8)\end{array}$ & $\begin{array}{l}1.0 \\
1.0 \\
1.0\end{array}$ & $\begin{array}{l}\text { Ref. } \\
\text { Ref. } \\
\text { Ref. }\end{array}$ & $\begin{array}{l}- \\
- \\
-\end{array}$ \\
\hline CCP-/CarP-Fib- & $\begin{array}{l}\text { Leiden EAC } \\
\text { Swedish EIRA } \\
\text { Meta-analysis }\end{array}$ & $\begin{array}{l}96(77.4) \\
165(77.5)\end{array}$ & $\begin{array}{l}28(22.6) \\
48(22.5)\end{array}$ & $\begin{array}{l}1.50 \\
1.48 \\
1.49\end{array}$ & $\begin{array}{l}0.92 \text { to } 2.44 \\
0.96 \text { to } 2.29 \\
1.08 \text { to } 2.06\end{array}$ & $\begin{array}{l}0.11 \\
0.08 \\
0.016\end{array}$ & $\begin{array}{r}95(56.5) \\
127(59.1)\end{array}$ & $\begin{array}{l}73(43.5) \\
88(40.9)\end{array}$ & $\begin{array}{l}1.90 \\
1.37 \\
1.61\end{array}$ & $\begin{array}{l}1.34 \text { to } 2.69 \\
0.97 \text { to } 1.93 \\
1.17 \text { to } 2.22\end{array}$ & $\begin{array}{r}<0.001 \\
0.074 \\
0.004\end{array}$ \\
\hline CCP-/CarP-Fib+ & $\begin{array}{l}\text { Leiden EAC } \\
\text { Swedish EIRA } \\
\text { Meta-analysis }\end{array}$ & $\begin{array}{l}8(50.0) \\
19(73.1)\end{array}$ & $\begin{array}{l}8(50.0) \\
7(26.9)\end{array}$ & $\begin{array}{l}5.13 \\
1.27 \\
2.54\end{array}$ & $\begin{array}{l}1.87 \text { to } 14.10 \\
0.48 \text { to } 3.38 \\
0.65 \text { to } 9.96\end{array}$ & $\begin{array}{l}0.002 \\
0.63 \\
0.18\end{array}$ & $\begin{array}{r}7(58.3) \\
16(64.0)\end{array}$ & $\begin{array}{l}5(41.7) \\
9(36.0)\end{array}$ & $\begin{array}{l}1.77 \\
1.21 \\
1.39\end{array}$ & $\begin{array}{l}0.55 \text { to } 5.64 \\
0.51 \text { to } 2.88 \\
0.69 \text { to } 2.78\end{array}$ & $\begin{array}{l}0.34 \\
0.67 \\
0.36\end{array}$ \\
\hline $\mathrm{CCP}+/ \mathrm{CarP}-\mathrm{Fib}-$ & $\begin{array}{l}\text { Leiden EAC } \\
\text { Swedish EIRA } \\
\text { Meta-analysis }\end{array}$ & $\begin{array}{l}53(76.8) \\
148(75.1)\end{array}$ & $\begin{array}{l}16(23.2) \\
49(24.9)\end{array}$ & $\begin{array}{l}1.55 \\
1.65 \\
1.62\end{array}$ & $\begin{array}{l}0.84 \text { to } 2.86 \\
1.07 \text { to } 2.55 \\
1.13 \text { to } 2.30\end{array}$ & $\begin{array}{l}0.16 \\
0.024 \\
0.008\end{array}$ & $\begin{array}{l}24(68.6) \\
36(55.4)\end{array}$ & $\begin{array}{l}11(31.4) \\
29(44.6)\end{array}$ & $\begin{array}{l}1.13 \\
1.74 \\
1.49\end{array}$ & $\begin{array}{l}0.55 \text { to } 2.36 \\
1.01 \text { to } 3.01 \\
0.96 \text { to } 2.31\end{array}$ & $\begin{array}{l}0.74 \\
0.046 \\
0.07\end{array}$ \\
\hline CCP+/CarP-Fib+ & $\begin{array}{l}\text { Leiden EAC } \\
\text { Swedish EIRA } \\
\text { Meta-analysis }\end{array}$ & $\begin{array}{l}119(81.0) \\
205(86.1)\end{array}$ & $\begin{array}{l}28(19.0) \\
33(13.9)\end{array}$ & $\begin{array}{l}1.21 \\
0.90 \\
1.04\end{array}$ & $\begin{array}{l}0.75 \text { to } 1.95 \\
0.56 \text { to } 1.44 \\
0.75 \text { to } 1.46\end{array}$ & $\begin{array}{l}0.44 \\
0.65 \\
0.81\end{array}$ & $\begin{array}{l}31(70.5) \\
47(74.6)\end{array}$ & $\begin{array}{l}13(29.5) \\
16(25.4)\end{array}$ & $\begin{array}{l}1.04 \\
0.68 \\
0.83\end{array}$ & $\begin{array}{l}0.53 \text { to } 2.03 \\
0.36 \text { to } 1.27 \\
0.52 \text { to } 1.31\end{array}$ & $\begin{array}{l}0.91 \\
0.22 \\
0.43\end{array}$ \\
\hline
\end{tabular}

respect, and we have focused on the anti-CarP antibodies. ${ }^{21}$ These anti-CarP antibodies were initially identified in adult RA patients and patients suffering from arthralgia, ${ }^{9} 10$ but have now also been described to occur in juvenile idiopathic arthritis, in both the ACPA-positive and the ACPA-negative subgroups. $^{22}$

In the current analyses of two large early RA cohorts, the presence of anti-CarP antibodies in the anti-CCP-negative stratum, originally described in the Leiden EAC, was confirmed in the EIRA cohort with comparable proportions of presence. This finding lends further support to the current assumption that besides a cross-reactive component of the ACPA/anti-CarP antibody responses, there are also antibodies directed against only citrullinated or only carbamylated proteins. ${ }^{23}$ Comparing the information obtained with the anti-CarP-Fib- and anti-CarP-FCS-assays thus far, the notion arises that the anti-CarP-FCS assay may provide more unique information than the anti-CarP-Fib assay as the latter shows a stronger association with the same risk factors as anti-CCP2. ${ }^{9}{ }^{23}$ The specificity of anti-CarP antibodies for RA in the setting of an outpatient rheumatology clinic/among patients with early arthritis has not been reported thus far and is the subject of further studies.
Given the differences mentioned above, it is not unlikely that anti-CarP-FCS and anti-CarP-Fib will display (slightly) different specificity/sensitivity profiles in such settings.

Carbamylation is a chemical post-translational modification mediated via cyanate, which is present in the body in equilibrium with urea. ${ }^{24}$ There are several factors that can shift the balance towards more cyanate and hence more carbamylation. Among these factors, renal dysfunction, inflammation and smoking are considered most important. ${ }^{24}$ Therefore, in this study we have specifically analysed to which extent the smoking status of the RA patients is associated with the presence of anti-CarP antibodies. However, we did not obtain evidence to support the hypothesis that smoking would induce anti-CarP antibodies nor did we find a specific association between anti-CarP antibodies and the PTPN22 polymorphism or HLA-DRB1-SE alleles. This lack of association might indicate a different biological mechanism leading to anti-CarP antibody formation compared with anti-CCP antibody formation.

With regard to HLA-DRB1 alleles, we could not identify any specific association with anti-CarP autoantibodies, although we cannot exclude an association between $H L A-D R B 1 * 03$ and anti-CCP-negative anti-CarP-FCS-positive RA. Since we also 
Table 3 Meta-analysis for disease risk in different rheumatoid arthritis (RA) subgroups divided by the presence/absence of anti-CarP and anticyclic citrullinated peptide (anti-CCP) antibodies, any PTPN22 allele carriers compared with non-carriers

\begin{tabular}{|c|c|c|c|c|c|c|}
\hline \multirow[b]{2}{*}{ Group } & \multirow[b]{2}{*}{ Cohort } & \multicolumn{2}{|l|}{ PTPN22 } & \multirow[b]{2}{*}{$\mathrm{OR}^{*}$} & \multirow[b]{2}{*}{$95 \% \mathrm{Cl}$} & \multirow[b]{2}{*}{$p$ Value } \\
\hline & & None N (\%) & Any N (\%) & & & \\
\hline \multicolumn{7}{|l|}{ CarP-FCS } \\
\hline Controls & $\begin{array}{l}\text { Leiden EAC } \\
\text { Swedish EIRA } \\
\text { Meta-analysis }\end{array}$ & $\begin{array}{r}338(82.2) \\
1010(78.7)\end{array}$ & $\begin{array}{r}73(17.8) \\
274(21.3)\end{array}$ & $\begin{array}{l}1.0 \\
1.0 \\
1.0\end{array}$ & $\begin{array}{l}\text { Ref. } \\
\text { Ref. } \\
\text { Ref. }\end{array}$ & $\begin{array}{l}- \\
- \\
-\end{array}$ \\
\hline CCP-/CarP-FCS- & $\begin{array}{l}\text { Leiden EAC } \\
\text { Swedish EIRA } \\
\text { Meta-analysis }\end{array}$ & $\begin{array}{l}200(80.0) \\
464(74.0)\end{array}$ & $\begin{array}{r}50(20.0) \\
163(26.0)\end{array}$ & $\begin{array}{l}1.16 \\
1.35 \\
1.30\end{array}$ & $\begin{array}{l}0.78 \text { to } 1.73 \\
1.07 \text { to } 1.69 \\
1.07 \text { to } 1.59\end{array}$ & $\begin{array}{l}0.47 \\
0.011 \\
0.009\end{array}$ \\
\hline CCP-/CarP-FCS+ & $\begin{array}{l}\text { Leiden EAC } \\
\text { Swedish EIRA } \\
\text { Meta-analysis }\end{array}$ & $\begin{array}{l}38(86.4) \\
54(63.5)\end{array}$ & $\begin{array}{r}6(13.6) \\
31(36.5)\end{array}$ & $\begin{array}{l}0.73 \\
2.16 \\
1.35\end{array}$ & $\begin{array}{l}0.30 \text { to } 1.79 \\
1.35 \text { to } 3.46 \\
0.47 \text { to } 3.86\end{array}$ & $\begin{array}{l}0.49 \\
0.001 \\
0.58\end{array}$ \\
\hline $\mathrm{CCP}+/ \mathrm{CarP}-\mathrm{FCS}-$ & $\begin{array}{l}\text { Leiden EAC } \\
\text { Swedish EIRA } \\
\text { Meta-analysis }\end{array}$ & $\begin{array}{r}65(73.9) \\
435(69.8)\end{array}$ & $\begin{array}{r}23(26.1) \\
188(30.2)\end{array}$ & $\begin{array}{l}1.64 \\
1.63 \\
1.63\end{array}$ & $\begin{array}{l}0.96 \text { to } 2.81 \\
1.31 \text { to } 2.04 \\
1.33 \text { to } 2.00\end{array}$ & $\begin{array}{c}0.07 \\
<0.001 \\
<0.001\end{array}$ \\
\hline CCP+/CarP-FCS+ & $\begin{array}{l}\text { Leiden EAC } \\
\text { Swedish EIRA } \\
\text { Meta-analysis }\end{array}$ & $\begin{array}{l}182(71.7) \\
414(68.1)\end{array}$ & $\begin{array}{r}72(28.3) \\
194(31.9)\end{array}$ & $\begin{array}{l}1.83 \\
1.78 \\
1.79\end{array}$ & $\begin{array}{l}1.26 \text { to } 2.66 \\
1.43 \text { to } 2.22 \\
1.48 \text { to } 2.17\end{array}$ & $\begin{array}{r}0.001 \\
<0.001 \\
<0.001\end{array}$ \\
\hline \multicolumn{7}{|l|}{ CarP-Fib } \\
\hline Controls & $\begin{array}{l}\text { Leiden EAC } \\
\text { Swedish EIRA } \\
\text { Meta-analysis }\end{array}$ & $\begin{array}{r}338(82.2) \\
1010(78.7)\end{array}$ & $\begin{array}{r}73(17.8) \\
274(21.3)\end{array}$ & $\begin{array}{l}1.0 \\
1.0 \\
1.0\end{array}$ & $\begin{array}{l}\text { Ref. } \\
\text { Ref. } \\
\text { Ref. }\end{array}$ & $\begin{array}{l}- \\
- \\
-\end{array}$ \\
\hline CCP-/CarP-Fib- & $\begin{array}{l}\text { Leiden EAC } \\
\text { Swedish EIRA } \\
\text { Meta-analysis }\end{array}$ & $\begin{array}{l}225(81.5) \\
457(73.4)\end{array}$ & $\begin{array}{r}51(18.5) \\
166(26.6)\end{array}$ & $\begin{array}{l}1.05 \\
1.38 \\
1.26\end{array}$ & $\begin{array}{l}0.71 \text { to } 1.56 \\
1.10 \text { to } 1.74 \\
0.98 \text { to } 1.62\end{array}$ & $\begin{array}{l}0.81 \\
0.005 \\
0.07\end{array}$ \\
\hline CCP-/CarP-Fib+ & $\begin{array}{l}\text { Leiden EAC } \\
\text { Swedish EIRA } \\
\text { Meta-analysis }\end{array}$ & $\begin{array}{l}20(76.9) \\
61(68.5)\end{array}$ & $\begin{array}{r}6(23.1) \\
28(31.5)\end{array}$ & $\begin{array}{l}1.39 \\
1.80 \\
1.71\end{array}$ & $\begin{array}{l}0.54 \text { to } 3.58 \\
1.12 \text { to } 2.90 \\
1.12 \text { to } 2.61\end{array}$ & $\begin{array}{l}0.50 \\
0.016 \\
0.014\end{array}$ \\
\hline $\mathrm{CCP}+/$ CarP-Fib- & $\begin{array}{l}\text { Leiden EAC } \\
\text { Swedish EIRA } \\
\text { Meta-analysis }\end{array}$ & $\begin{array}{r}89(75.4) \\
354(72.4)\end{array}$ & $\begin{array}{r}29(24.6) \\
135(27.6)\end{array}$ & $\begin{array}{l}1.51 \\
1.46 \\
1.47\end{array}$ & $\begin{array}{l}0.93 \text { to } 2.46 \\
1.15 \text { to } 1.87 \\
1.18 \text { to } 1.83\end{array}$ & $\begin{array}{l}0.10 \\
0.002 \\
0.001\end{array}$ \\
\hline $\mathrm{CCP}+/$ CarP-Fib+ & $\begin{array}{l}\text { Leiden EAC } \\
\text { Swedish EIRA } \\
\text { Meta-analysis }\end{array}$ & $\begin{array}{l}163(70.6) \\
495(66.7)\end{array}$ & $\begin{array}{r}68(29.4) \\
247(33.3)\end{array}$ & $\begin{array}{l}1.93 \\
1.87 \\
1.88\end{array}$ & $\begin{array}{l}1.32 \text { to } 2.82 \\
1.52 \text { to } 2.30 \\
1.57 \text { to } 2.26\end{array}$ & $\begin{array}{r}0.001 \\
<0.001 \\
<0.001\end{array}$ \\
\hline
\end{tabular}

observed an association between this HLA allele and the CCP/ CarP-FCS double-negative RA subgroup, this precludes any definitive conclusions about whether the association is specific for anti-CarP-FCS-positive RA or not. The HLA-DRB1*03 association was stronger with anti-CarP-FCS-positive subgroup than with the double-negative subgroup (ORs were approximately 2.5 for CCP-/CarP-FCS + RA vs 1.5 for CCP-/CarP-FCS- RA), although this difference was not statistical significant, potentially due to lack of power as a consequence of the rather limited numbers of $\mathrm{CCP}-/ \mathrm{CarP}-\mathrm{FCS}+$ patients. Hence, whether HLA-DRB1*03 is involved in the formation of anti-CarP antibodies needs further investigation.

There are several limitations to the current study, mainly concerning the breadth of autoantibodies and genetics risk factors that were investigated. With regard to autoantibodies, the scope was limited to anti-CCP2 antibodies, although ACPA reactive with citrullinated epitopes on $\alpha$-enolase, vimentin, fibrinogen and collagen type II have been detected in anti-CCP-negative RA. $^{20}$ It is thus possible that the anti-CarP antibody-positive subset of the anti-CCP antibody-negative RA population in fact also contains ACPA fine specificities that were captured by the anti-CCP2 detection kit. Likewise, RFs could be present in the anti-CCP-negative/anti-CarP-positive subset. This is the subject of an ongoing investigation. Regarding the genetic and environmental risk factors, we cannot exclude that there are other genes, not investigated here, which may also be of importance for the development of anti-CarP-positive RA. Although the combination of two cohorts allowed us to include a large number of patients in our analyses, the smaller size of some of the subgroups may still have led to some power limitations as described above.

Whereas most studies up to date have focused on ACPA-positive RA regarding investigation of genetic and environmental risk factors, with this study we wished to move the field forward by analysing a subset of ACPA-negative RA patients, those positive for anti-CarP antibodies, for specific associations regarding the major genetic and environmental risk factors described for RA. Interestingly, we did not obtain evidence for a specific association of anti-CarP antibody with HLA-SE alleles, PTPN22 variants or smoking, but we did find an association between HLA-DRB1*03 and anti-CarP-FCS antibodies. These data suggest that anti-CarP antibody induction may be facilitated by different mechanisms than the ones involved in the induction of ACPA.

In conclusion, anti-CarP antibodies are present in ACPA-positive and ACPA-negative RA patients in both EAC and EIRA cohorts. We did not find any association among anti-CarP antibodies and smoking, PTPN22 or HLA-DRB1 alleles, with the exception of the association identified between anti-CarP-FCS antibodies and HLA-DRB1*03. 
Table 4 Meta-analysis for disease risk in different rheumatoid arthritis (RA) subgroups divided by the presence/absence of anti-CarP and anticyclic citrullinated peptide (anti-CCP) antibodies, ever smokers compared with non-smokers

\begin{tabular}{|c|c|c|c|c|c|c|}
\hline \multirow[b]{2}{*}{ Group } & \multirow[b]{2}{*}{ Cohort } & \multicolumn{2}{|l|}{ Smoking } & \multirow[b]{2}{*}{$\mathrm{OR}^{*}$} & \multirow[b]{2}{*}{$95 \% \mathrm{Cl}$} & \multirow[b]{2}{*}{ p Value } \\
\hline & & Never N (\%) & Ever N (\%) & & & \\
\hline \multicolumn{7}{|l|}{ CarP-FCS } \\
\hline CCP-/CarP-FCS- (as control group) & $\begin{array}{l}\text { Leiden EAC } \\
\text { Swedish EIRA } \\
\text { Meta-analysis }\end{array}$ & $\begin{array}{l}160(52.0) \\
247(44.5)\end{array}$ & $\begin{array}{l}148(48.0) \\
308(55.5)\end{array}$ & $\begin{array}{l}1.0 \\
1.0 \\
1.0\end{array}$ & $\begin{array}{l}\text { Ref. } \\
\text { Ref. } \\
\text { Ref. }\end{array}$ & $\begin{array}{l}- \\
- \\
-\end{array}$ \\
\hline CCP-/CarP-FCS+ & $\begin{array}{l}\text { Leiden EAC } \\
\text { Swedish EIRA } \\
\text { Meta-analysis }\end{array}$ & $\begin{array}{l}31(55.4) \\
24(32.9)\end{array}$ & $\begin{array}{l}25(44.6) \\
49(67.1)\end{array}$ & $\begin{array}{l}0.87 \\
1.67 \\
1.21\end{array}$ & $\begin{array}{l}0.49 \text { to } 1.55 \\
0.96 \text { to } 2.89 \\
0.64 \text { to } 2.30\end{array}$ & $\begin{array}{l}0.64 \\
0.07 \\
0.56\end{array}$ \\
\hline $\mathrm{CCP}+/ \mathrm{CarP}-\mathrm{FCS}-$ & $\begin{array}{l}\text { Leiden EAC } \\
\text { Swedish EIRA } \\
\text { Meta-analysis }\end{array}$ & $\begin{array}{r}51(51.5) \\
195(35.2)\end{array}$ & $\begin{array}{r}48(48.5) \\
359(64.8)\end{array}$ & $\begin{array}{l}1.02 \\
1.58 \\
1.32\end{array}$ & $\begin{array}{l}0.65 \text { to } 1.60 \\
1.22 \text { to } 2.04 \\
0.87 \text { to } 2.02\end{array}$ & $\begin{array}{c}0.94 \\
<0.001 \\
0.19\end{array}$ \\
\hline $\mathrm{CCP}+/ \mathrm{CarP}-\mathrm{FCS}+$ & $\begin{array}{l}\text { Leiden EAC } \\
\text { Swedish EIRA } \\
\text { Meta-analysis }\end{array}$ & $\begin{array}{l}119(41.0) \\
141(25.9)\end{array}$ & $\begin{array}{l}171(59.0) \\
404(74.1)\end{array}$ & $\begin{array}{l}1.55 \\
2.27 \\
1.90\end{array}$ & $\begin{array}{l}1.12 \text { to } 2.15 \\
1.73 \text { to } 2.97 \\
1.31 \text { to } 2.76\end{array}$ & $\begin{array}{r}0.008 \\
<0.001 \\
<0.001\end{array}$ \\
\hline \multicolumn{7}{|l|}{ CarP-Fib } \\
\hline CCP-/CarP-Fib- (as control group) & $\begin{array}{l}\text { Leiden EAC } \\
\text { Swedish EIRA } \\
\text { Meta-analysis }\end{array}$ & $\begin{array}{l}193(52.2) \\
235(43.2)\end{array}$ & $\begin{array}{l}177(47.8) \\
309(56.8)\end{array}$ & $\begin{array}{l}1.0 \\
1.0 \\
1.0\end{array}$ & $\begin{array}{l}\text { Ref. } \\
\text { Ref. } \\
\text { Ref. }\end{array}$ & $\begin{array}{l}- \\
- \\
-\end{array}$ \\
\hline $\mathrm{CCP}-/$ CarP-Fib+ & $\begin{array}{l}\text { Leiden EAC } \\
\text { Swedish EIRA } \\
\text { Meta-analysis }\end{array}$ & $\begin{array}{l}17(50.0) \\
36(42.9)\end{array}$ & $\begin{array}{l}17(50.0) \\
48(57.1)\end{array}$ & $\begin{array}{l}1.09 \\
0.99 \\
1.02\end{array}$ & $\begin{array}{l}0.54 \text { to } 2.20 \\
0.61 \text { to } 1.61 \\
0.69 \text { to } 1.52\end{array}$ & $\begin{array}{l}0.81 \\
0.96 \\
0.92\end{array}$ \\
\hline $\mathrm{CCP}+/$ CarP-Fib- & $\begin{array}{l}\text { Leiden EAC } \\
\text { Swedish EIRA } \\
\text { Meta-analysis }\end{array}$ & $\begin{array}{r}73(45.6) \\
146(33.4)\end{array}$ & $\begin{array}{r}87(54.4) \\
291(66.6)\end{array}$ & $\begin{array}{l}1.30 \\
1.60 \\
1.49\end{array}$ & $\begin{array}{l}0.90 \text { to } 1.89 \\
1.21 \text { to } 2.11 \\
1.19 \text { to } 1.86\end{array}$ & $\begin{array}{c}0.17 \\
<0.001 \\
<0.001\end{array}$ \\
\hline $\mathrm{CCP}+/ \mathrm{CarP}-\mathrm{Fib}+$ & $\begin{array}{l}\text { Leiden EAC } \\
\text { Swedish EIRA } \\
\text { Meta-analysis }\end{array}$ & $\begin{array}{l}118(41.0) \\
190(28.7)\end{array}$ & $\begin{array}{l}170(59.0) \\
472(71.3)\end{array}$ & $\begin{array}{l}1.57 \\
1.90 \\
1.76\end{array}$ & $\begin{array}{l}1.15 \text { to } 2.14 \\
1.48 \text { to } 2.45 \\
1.45 \text { to } 2.14\end{array}$ & $\begin{array}{r}0.004 \\
<0.001 \\
<0.001\end{array}$ \\
\hline
\end{tabular}

\section{Author affiliations}

${ }^{1}$ Institute of Environmental Medicine, Karolinska Institutet, Stockholm, Sweden ${ }^{2}$ Department of Rheumatology, Leiden University Medical Center, Leiden, The Netherlands

${ }^{3}$ Rheumatology Unit, Department of Medicine, Karolinska Institutet, Stockholm, Sweden

${ }^{4}$ Department of Immunohematology and Blood Transfusion, Leiden University Medical Center, Leiden, The Netherlands

${ }^{5}$ Center for Occupational and Environmental Medicine, Stockholm County Council, Stockholm, Sweden

Acknowledgements The authors thank the investigators and study participants from the EIRA study and the EAC study.

Contributors XJ, LAT, KL and DvdW had main responsibility for the study, including design, experimental set-up, analyses, tables, figures and writing the paper. TJvW, JS, LI and $\mathrm{HH}$ were involved in the planning and execution of the experiments. CB, HK, VM, LK, LA, TWJH and REMT were involved in supervising, data analyses and writing the paper. All authors contributed to and agreed with the final version of the paper.

Funding This work was supported with grants from the IMI JU funded project BTCure (contract No. 115142-2); the EU projects Masterswitch (contract No. 2.4.5-12), Gums\&Joints (contract No. 261460) and Trigger (contract No. 306029); the Swedish Research Council, the Swedish Rheumatic Foundation, and the Swedish Medical Research Council for Health, Working Life and Welfare; the Swedish AFA insurance; the Netherlands Proteomics Center and the Center for Medical Systems Biology as part of The Netherlands Genomics Initiative. LT is supported by a NWO ZON-MW Vidi grant and by a fellowship from Janssen Biologics. DvdW is supported by a NWO ZON-MW Agiko grant.

Competing interests None.

Patient consent Obtained.

Ethics approval All aspects of this study were approved by the Leiden University Medical Center (LUMC) and Karolinska Institutet (KI) institutional review boards.

Provenance and peer review Not commissioned; externally peer reviewed.

\section{REFERENCES}

1 Aletaha D, Neogi T, Silman AJ, et al. 2010 Rheumatoid arthritis classification criteria: an American College of Rheumatology/European League Against Rheumatism collaborative initiative. Arthritis Rheum 2010;62:2569-81.

2 Turesson C, Jacobsson LT, Sturfelt G, et al. Rheumatoid factor and antibodies to cyclic citrullinated peptides are associated with severe extra-articular manifestations in rheumatoid arthritis. Ann Rheum Dis 2007;66:59-64.

3 van der Helm-van Mil AH, Verpoort KN, Breedveld FC, et al. Antibodies to citrullinated proteins and differences in clinical progression of rheumatoid arthritis. Arthritis Res Ther 2005;7:R949-58.

4 Nielen MM, van Schaardenburg D, Reesink HW, et al. Specific autoantibodies precede the symptoms of rheumatoid arthritis: a study of serial measurements in blood donors. Arthritis Rheum 2004;50:380-6.

5 Rantapaa-Dahlqvist $\mathrm{S}$, de Jong BA, Berglin E, et al. Antibodies against cyclic citrullinated peptide and IgA rheumatoid factor predict the development of rheumatoid arthritis. Arthritis Rheum 2003;48:2741-9.

6 Huizinga TW, Amos $\mathrm{Cl}$, van der Helm-van Mil AH, et al. Refining the complex rheumatoid arthritis phenotype based on specificity of the HLA-DRB1 shared epitope for antibodies to citrullinated proteins. Arthritis Rheum 2005;52:3433-8.

7 Kallberg H, Padyukov L, Plenge RM, et al. Gene-gene and gene-environment interactions involving HLA-DRB1, PTPN22, and smoking in two subsets of rheumatoid arthritis. Am J Hum Genet 2007;80:867-75.

8 Klareskog L, Stolt $\mathrm{P}$, Lundberg $\mathrm{K}$, et al. A new model for an etiology of rheumatoid arthritis: smoking may trigger HLA-DR (shared epitope)-restricted immune reactions to autoantigens modified by citrullination. Arthritis Rheum 2006;54:38-46.

9 Shi J, Knevel R, Suwannalai P, et al. Autoantibodies recognizing carbamylated proteins are present in sera of patients with rheumatoid arthritis and predict joint damage. Proc Natl Acad Sci USA 2011;108:17372-7.

10 Shi J, van de Stadt LA, Levarht EW, et al. Anti-carbamylated protein antibodies are present in arthralgia patients and predict the development of rheumatoid arthritis. Arthritis Rheum 2013;65:911-15.

11 Arnett FC, Edworthy SM, Bloch DA, et al. The American Rheumatism Association 1987 revised criteria for the classification of rheumatoid arthritis. Arthritis Rheum 1988;31:315-24

12 Bengtsson C, Berglund A, Serra ML, et al. Non-participation in EIRA: a populationbased case-control study of rheumatoid arthritis. Scand J Rheumatol 2010;39:344-6. 
13 van Aken J, van Bilsen JH, Allaart CF, et al. The Leiden Early Arthritis Clinic. Clin Exp Rheumatol 2003;21:S100-105.

14 Padyukov L, Silva C, Stolt P, et al. A gene-environment interaction between smoking and shared epitope genes in HLA-DR provides a high risk of seropositive rheumatoid arthritis. Arthritis Rheum 2004:50:3085-92.

15 van der Helm-van Mil AH, Huizinga TW, Schreuder GM, et al. An independent role of protective HLA class II alleles in rheumatoid arthritis severity and susceptibility. Arthritis Rheum 2005;52:2637-44.

16 Plenge RM, Padyukov L, Remmers EF, et al. Replication of putative candidate-gene associations with rheumatoid arthritis in $>4,000$ samples from North America and Sweden: association of susceptibility with PTPN22, CTLA4, and PADI4. Am I Hum Genet 2005;77:1044-60.

17 Feitsma AL, Toes RE, Begovich AB, et al. Risk of progression from undifferentiated arthritis to rheumatoid arthritis: the effect of the PTPN22 1858T-allele in anti-citrullinated peptide antibody positive patients. Rheumatology (Oxford) 2007;46:1092-5.

18 Stolt P, Bengtsson C, Nordmark B, et al. Quantification of the influence of cigarette smoking on rheumatoid arthritis: results from a population based case-control study, using incident cases. Ann Rheum Dis 2003;62:835-41.
19 Willemze $A$, van der Woude $D$, Ghidey W, et al. The interaction between HLA shared epitope alleles and smoking and its contribution to autoimmunity against several citrullinated antigens. Arthritis Rheum 2011:63:1823-32.

20 Lundberg K, Bengtsson C, Kharlamova N, et al. Genetic and environmental determinants for disease risk in subsets of rheumatoid arthritis defined by the anticitrullinated protein/peptide antibody fine specificity profile. Ann Rheum Dis 2013;72:652-8

21 Trouw LA, Mahler M. Closing the serological gap: promising novel biomarkers for the early diagnosis of rheumatoid arthritis. Autoimmun Rev 2012;

12:318-22.

22 Hissink Muller PC, Anink J, Shi J, et al. Anticarbamylated protein (anti-CarP) antibodies are present in sera of juvenile idiopathic arthritis (JIA) patients. Ann Rheum Dis 2013;72:2053-5.

23 Shi J, Willemze A, Janssen GM, et al. Recognition of citrullinated and carbamylated proteins by human antibodies: specificity, cross-reactivity and the 'AMC-Senshu' method. Ann Rheum Dis 2013;72:148-50.

24 Trouw LA, Huizinga TW, Toes RE. Autoimmunity in rheumatoid arthritis: different antigens--common principles. Ann Rheum Dis 2013;72(Suppl 2):ii132-6. 